\title{
The Influence of Emotional Intelligence and Interpersonal Communication on Employees' Work Satisfaction at Education and Culture Office in West Kalimantan
}

\author{
Erna Oktafiani ${ }^{1)}$, M. Chiar ${ }^{2)}$, Sukmawati ${ }^{3)}$ \\ ${ }^{1)}$ Universitas Tanjungpura, Pontianak, Indonesia \\ E-mail:erna97@gmail.com \\ ${ }^{2)}$ Universitas Tanjungpura, Pontianak, Indonesia \\ E-mail: chiarfkip@gmail.com \\ ${ }^{3)}$ Universitas Tanjungpura, Pontianak, Indonesia \\ E-mail:sukmawati@fkip.untan.ac.id
}

\begin{abstract}
The process of reorganization of the application of Law Number 23 of 2014 concerning Regional Government, the moratorium of civil servants and the limited quota of participants on attending education and training leads to two factors of job satisfaction, namely organization, and management. This study aims to (1) determine the influence of leadership emotional intelligence with job satisfaction of employees of the Department of Education and Culture of West Kalimantan Province; (2) To determine the effect of interpersonal communication with job satisfaction of employees of the Department of Education and Culture of West Kalimantan Province; (3) To determine the influence of leadership emotional intelligence and interpersonal communication on job satisfaction of employees of the Department of Education and Culture of West Kalimantan Province. The results obtained from this study are the emotional intelligence of leaders significantly influence the job satisfaction of employees of the Department of Education and Culture of West Kalimantan Province, which means that the better the emotional intelligence of their leaders, the higher the job satisfaction of employees of the West Kalimantan Provincial Education and Culture Office. Second, interpersonal communication has a significant effect on the job satisfaction of employees of the Department of Education and Culture of West Kalimantan Province, which means that the better interpersonal communication that exists between employees of the Department of Education and Culture of West Kalimantan Province, the higher the job satisfaction of employees. Third, leadership emotional intelligence and interpersonal communication together have a significant effect on job satisfaction of employees of the Department of Education and Culture of West Kalimantan Province. It means that the better the emotional intelligence of leaders and interpersonal communication that exists between employees of the Department of Education and Culture of West Kalimantan Province, the higher the job satisfaction of the employees.
\end{abstract}

Keywords: Emotional Intelligence; Interpersonal Communication; Work Satisfaction

\section{INTRODUCTION}

Job satisfaction is something that is individual, meaning that each has a difference in job satisfaction. Experts define job satisfaction as a positive feeling emanating in the sense of pleasure or happiness in their work. This sense of pleasure will ultimately affect the quality of the work of the employee concerned.

This sense of pleasure is influenced by various things including the type of work itself, which is related to whether the work charged to an employee is by his capacity. In addition, the condition of the organization and the ability to supervise the leaders also become one of the important aspects of job satisfaction, about how the organization regulates itself and how the leadership in managing it. Then it is related to the welfare of employees and the opportunity to go forward given to employees, whether it is appropriate or not. Job satisfaction is also influenced by the system of rewards and punishments that are enforced, the environmental conditions of the work environment, as well as the communication that exists there.

In looking at employee job satisfaction, a benchmark is needed for each aspect. This benchmark will be a reference for determining the level of job satisfaction of employees in an organization. The indicators that can be used to see are among others the suitability of work with the education and competence of its employees, the existence of clear regulations and standard 
procedures in carrying out services. Then also related to the involvement of work, supervision, and direction of the leader, the assessment system, income, health facilities, career paths, and the opportunity to attend training. In addition, it can also use indicators of interpersonal communication that occur as well as supportive working environment conditions.

Job satisfaction becomes an important and interesting thing for the progress of an organization. Various kinds of research on job satisfaction show its benefits for individuals, organizations, and society in general as connoisseurs of organizational work. Employees with good job satisfaction tend to display their best work, and vice versa employees with low job satisfaction tend to produce work that is not optimal. Therefore, to maintain organizational stability, employee job satisfaction must be maintained even if the balance is increased continuously.

A good and stable organization should also be accompanied by high employee job satisfaction. However, the results of a temporary interview with the Secretary of the Office of Education and Culture of West Kalimantan Province found that in reality, the Office of Education and Culture of West Kalimantan Province was still in the process of reorganization of the application of Law Number 23 of 2014 concerning Regional Government. The law mandates the transfer of senior high school management authority to the provincial service. This process results in changes in the organizational structure that has an impact on the number of new jobs that do not have work instructions so that in carrying out service activities experience obstacles.

The process of organizational change or called institutional transformation that takes a long time to reach $100 \%$ is a challenge. Coupled with leadership changes made by auctioning positions to make elected leaders do not always have an educational background to be an obstacle in making organizational decisions.

This situation is compounded by the ongoing moratorium on civil servant (PNS) acceptance, making the Department of Education and Culture of West Kalimantan Province unable to recruit civil servants. As a result, the availability of productive and competent employees is very limited because the older generation dominates employees with various limitations. These limitations include limited knowledge, insight, mastery of technology, as well as accuracy and speed in performing services.

The Office of Education and Culture of West Kalimantan Province has a large number of employees, but when viewed from the quality and capability of its employees it can be said to be very far from adequacy. Until now, the addition of employees has been done by relying on graduates of the Institute of Internal Governance (IPDN). In addition, note that the number of IPDN alumni is limited and there is no certainty of the number of employees who will be placed in the Department of Education and Culture of West Kalimantan Province.
This limited condition of productive employees resulted in an unbalanced division of labor. Employees with better mastery of technology and insight will get more jobs, while employees with limited mastery will be given a job that matches their ability even in higher ranks and groups.

Other conditions are related to improving employee competencies in the form of training and education (education and training) held to reduce competency gaps. In practice, not all education and training is organized by the local government but also from the ministry which gives a very limited quota of participants for each year.

The limitation of employee quota to take part in the training resulted in the uneven distribution of competency opportunities. Not only is the opportunity not given, but also does not carry out the mandate contained in Law Number 5 of 2014 concerning State Civil Apparatus (ASN). This law mandates that each ASN must attend a competency development program through education and training for at least 40 hours in a fiscal year. Thus it can be seen that the mandate of the ASN Law cannot all be implemented and not all employees have the opportunity to attend the necessary education and training.

All these discrepancies lead to two factors of job satisfaction, namely organization and management, and communication. This factor influences the obscurity of the direction of the leader so that the role of the leader as a good communicator can help in finding solutions, striving for employees to get good resources and not being able to run properly.

In the organization and management, there must be the role of the leader and the person he leads or the staff. Leaders will do good management in an organization strongly influenced by the ability to manage their emotions. As mentioned by Kreitner and Kinicki (2014: 142) states that the ability to build a team, manage a team, work together and motivate a team towards a new direction is part of the implementation of the emotional intelligence of a leader. Leaders with good emotional intelligence will manage the team well too, motivating the team members to be creative and innovative towards new changes. Here is emotional intelligence plays a maximum role in improving the managerial quality of a leader, so even though the condition of the organization is still in the stage of change with the many things that are still arranged and managed, it is expected that employee job satisfaction remains high.

The experts define emotional intelligence as the ability to recognize emotions themselves, manage emotions, motivate themselves, recognize the emotions of others, and establish relationships with staff. Good emotional intelligence is influenced by several factors, namely the ability to recognize one's own emotions, manage emotions, motivate, empathy, and foster relationships with others.

The next variable related to the facts related to job satisfaction is interpersonal communication as mentioned by Sutrisno (2009: 82) that smooth communication between 
employees is one reason to love his job. In this case, including the willingness to hear, understand, acknowledge the opinions or achievements of employees, it has a great role in giving rise to satisfaction with his work. Indicators used to measure it include: open with new information and views, thinking before acting, realizing differences, acknowledging the feelings of others, honest responses, acknowledging mistakes, paying attention to intonation and sentences and meaning, focus, reciprocity, and showing support to opponents talk

Based on existing theories, it is a good organization ideally accompanied by high employee job satisfaction. Job satisfaction is influenced by managerial elements, wherein a capable managerial ability, good leadership emotional intelligence is needed. In addition, the establishment of good interpersonal communication between employees will make it easier for employees to love their work and feel happy for their work.

From the things encountered, the researcher has an interest in researching "The Effect of Emotional Intelligence and Interpersonal Communication on the Job Satisfaction of Staff of the Education and Culture Office of West Kalimantan Province."

\section{RESEARCH METHOD}

The research approach that will be used is a quantitative research approach concerning associative / relationship research. This study aims to determine the relationship between two or more variables. With this research, a theory can be built that can function to explain, predict and control a phenomenon (Sugiyono, 2015: 12). This study aims to test the validity of the hypothesis relating to the influence of emotional intelligence (X1) on employee job satisfaction (Y), interpersonal communication (X2) on employee satisfaction (Y) and emotional intelligence (X1) and interpersonal communication (X2) together affect employee job satisfaction (Y), as illustrated in the chart below.

In this study, the population of the research titled "The Effect of Emotional Intelligence and Interpersonal Communication on the Job Satisfaction of Department of Education and Culture Officers of West Kalimantan Province" are all employees of the Department of Education and Culture of West Kalimantan Province who are staff / implementers with a total population of 82 person.

\section{RESULT AND DISCUSSION}

\section{A. Result}

Description of the data to be presented from the results of this study is to provide a general description of the distribution of data obtained in the field. By doing the data description, we can see how the job satisfaction of employees in the Department of Education and Culture of West Kalimantan Province, how the emotional intelligence of the leaders in the
Department of Education and Culture of West Kalimantan Province, and how the conditions of interpersonal communication are intertwined in the West Kalimantan Provincial Education and Culture Office. There is also the data obtained will be described for each variable as follows.

a. Job Satisfaction of Employees of the Department of Education and Culture of West Kalimantan Province

Based on the results of statistical analysis, employee job satisfaction can be grouped into four categories: not good with a range of total scores (0 - 33), not good (33-66), good (67 - 99), and very good (100-132). The frequency distribution grouping as can be seen in Table I.

Table I

Distribution of Frequency of Employee Job Satisfaction by Category

\begin{tabular}{clccc}
\hline No & Category & Score Range & Frequency & Percentage \\
\hline 1 & Poor & $0-39$ & 0 & $0 \%$ \\
\hline 2 & Fair & $40-78$ & 0 & $0 \%$ \\
\hline 3 & Good & $79-117$ & 9 & $30 \%$ \\
\hline 4 & Very Good & $118-156$ & 21 & $70 \%$ \\
\hline \multicolumn{2}{r}{ Total } & & 30 & 100 \\
\hline
\end{tabular}

Data in Table I shows that job satisfaction of employees in the Department of Education and Culture of West Kalimantan Province is in the good and very good category. Most employees, as many as 21 people $(70 \%)$ have a perception that employee job satisfaction includes aspects of the type of work, organizational conditions and supervision, welfare, opportunities for advancement, awards and penalties, work environment, and communication in the Education and Culture Office of Kalimantan Province The West is very good.

In this job satisfaction variable, 33 statement items represent various indicators. This score is categorized according to its size with the following provisions: very high with a score of $91-120$, high with a score of $61-90$, currently with a score of $31-60$, and a low with a score of $0-30$.

Based on the results obtained, 25 statement items $(76 \%)$ got very high categories, and 8 statement items (24\%) were in the high category. It means that all aspects of employee job satisfaction are felt good by the employees of the Department of Education and Culture of West Kalimantan Province. However, it should be considered to keep improving the indicators with the lowest score, which include the availability of standard service procedures (SOP), training and seminar offered to provide opportunities for advancement, written appreciation of achievements, and communication with leaders that can be intensified.

b. Emotional Intelligence Leader of the Office of Education and Culture of West Kalimantan Province

Data obtained from filling out the emotional intelligence questionnaire by thirty employees of the Department of Education and Culture of West Kalimantan Province showed the following results: 
Based on the results of statistical analysis, leadership emotional intelligence can be grouped into four categories: not good with a total score range $(0-33)$, not good $(33-66)$, good (67 - 99), and very good (100-132). The frequency distribution grouping as can be seen in Table II.

Table II

Frequency Distribution of Emotional Intelligence by Category

\begin{tabular}{clccc}
\hline No & Category & Score Range & Frequency & Percentage \\
\hline 1 & Poor & $0-39$ & 0 & $0 \%$ \\
\hline 2 & Fair & $40-78$ & 0 & $0 \%$ \\
\hline 3 & Good & $79-117$ & 9 & $30 \%$ \\
\hline 4 & Very Good & $118-156$ & 21 & $70 \%$ \\
\hline \multicolumn{2}{r}{ Total } & 30 & 100 \\
\hline
\end{tabular}

Data in Table II showed that the emotional intelligence of the leaders in the Department of Education and Culture of West Kalimantan Province was in the good and very good category. Most of the employees, as many as 21 people (70\%) had a perception that the emotional intelligence of leaders which included aspects of self-emotion recognition, emotional management, empathy, and building relationships in the Department of Education and Culture of West Kalimantan Province was very good.

In addition, to find out how the conditions of each aspect of emotional intelligence of the leaders of the Office of Education and Culture of West Kalimantan Province on this emotional intelligence variable there are 34 statement items representing various indicators. This score is categorized according to its size with the following provisions: very high with a score of $91-120$, high with a score of $61-90$, moderate with a score of $31-60$, and a low category with a score of 0 30 .

Based on the results of the study that 34 statement items $(100 \%)$ get very high categories. It means that all aspects of the leadership's emotional intelligence are felt very well by the employees of the Department of Education and Culture of West Kalimantan Province. However, some indicators can still be improved because they get the lowest score even in the very high category. These indicators include recognizing the causes of emotions in the leadership themselves, the ability to accept different points of view, flexibility in socializing, ability to work together, and the attention of leaders to the staff that can still be improved.

c. Interpersonal Communication that is established in the Department of Education and Culture of West Kalimantan Province

Based on the results of statistical analysis, interpersonal communication can be grouped into four categories: not good with a range of total scores $(0-33)$, not good (33 - 66), good (67 - 99), and very good (100-132). The frequency distribution grouping as can be seen in Table III.
Table III

Interpersonal Communication Frequency Distribution by Category

\begin{tabular}{clccc}
\hline No & Category & Score Range & Frequency & Percentage \\
\hline 1 & Poor & $0-39$ & 0 & $0 \%$ \\
\hline 2 & Fair & $40-78$ & 0 & $0 \%$ \\
\hline 3 & Good & $79-117$ & 9 & $30 \%$ \\
\hline 4 & Very Good & $118-156$ & 21 & $70 \%$ \\
\hline \multicolumn{2}{r}{ Total } & & 30 & 100 \\
\hline
\end{tabular}

The data in Table III shows that interpersonal communication is intertwined in the Department of Education and Culture of West Kalimantan Province in the category of good and very good. Most employees, as many as 21 people (70\%) have the perception that interpersonal communication includes aspects of awareness, flexibility, oriented to others, openness, metacommunication, confidence, immediacy, support, and management of interaction in the Department of Education and Culture of West Kalimantan Province very good.

In addition, to find out how the conditions of each aspect of the variable interpersonal communication in the Department of Education and Culture of West Kalimantan Province in this variable interpersonal communication 32 statement items represent various indicators. This score is categorized according to its size with the following provisions: very high with a score of $91-120$, high with a score of $61-90$, currently with a score of $31-60$, and a low with a score of 0 30.

The results showed that 32 statement items (100\%) got very high categories. It means that all aspects of interpersonal communication are felt very well by the employees of the Department of Education and Culture of West Kalimantan Province. However, some indicators can still be improved because they get the lowest score even in very high categories. These indicators include openness to new information and views, expressing themselves (opinions/responses) when the time is right, showing a spontaneous response and honesty, explaining feelings that are in line with the mind, outlining the complexity of intentions, clarifying doubts, and confidence with initiative get acquainted which can still be improved.

1. Test Data Analysis Requirements

a. Data Normality Test

Based on the tests performed, it was found that the variables of job satisfaction $(p=0.200)$ and emotional intelligence variables $(p=0.113)$ had data with normal distribution. While the variables of interpersonal communication $(\mathrm{p}=0.043)$ have abnormal data distribution. Against the distribution of interpersonal communication data, data transformation tests have been conducted and still produce abnormal data distribution $(\mathrm{p}=$ $0.043)$.

b. Linearity Test

Statistical analysis shows that the relationship between emotional intelligence and job satisfaction 
variables is linear because of the significance value on deviation from linearity of $0.545(>0.05)$, as well as the relationship between variables of interpersonal communication with job satisfaction which has a significance value on deviation from linearity amounting to 0.935 (>0.05).

\section{Hypothesis Testing}

Testing the hypothesis in this test is to determine the effect of emotional intelligence variables (X1) on the variable job satisfaction (Y), the influence of interpersonal communication variables (X2) on the variable job satisfaction $(\mathrm{Y})$, and the influence of emotional intelligence variables (X1) and interpersonal communication variables. (X2) jointly to the variable job satisfaction (Y).

For more details the results of testing the hypothesis between the variables mentioned above will be explained below:

a. The Effect of Emotional Intelligence (X1) on Job Satisfaction (Y)

Based on the results of statistical tests it can be seen that the correlation between $\mathrm{X} 1$ and $\mathrm{Y}$ obtained a significance value of $p=0,000(p<0.05)$, which indicates that emotional intelligence has a significant effect on job satisfaction. Pearson value of 0.848 shows that a positive correlation with the strength of correlation ( $\mathrm{r}$ ) is very strong. It can be interpreted that the better the emotional intelligence of leaders in the Department of Education and Culture of West Kalimantan Province, the higher the job satisfaction of the employees.

b. Effect of Interpersonal Communication (X2) on Job Satisfaction (Y)

Based on the results of statistical tests it can be seen that the correlation between $\mathrm{X} 2$ and $\mathrm{Y}$ obtained a significance value of $\mathrm{p}=0.012$ ( $\mathrm{p}<0.05)$, which indicates that interpersonal communication has a significant effect on job satisfaction. The Spearman value of 0.451 shows that the positive correlation with the strength of the correlation $(r)$ is moderate. It can be interpreted that the better interpersonal communication established in the Department of Education and Culture of West Kalimantan Province, the higher the job satisfaction of the employees.

c. The Influence of Emotional Intelligence (X1) and Interpersonal Communication (X2) Together on Job Satisfaction (Y)

Based on the results of statistical analysis it can be seen that the influence of emotional intelligence and interpersonal communication variables together on job satisfaction shows $\mathrm{p}$ value $=0,000(p<0.05)$. Thus it can be concluded that there is a significant influence jointly between emotional intelligence and interpersonal communication on job satisfaction. It can be interpreted that the better the emotional intelligence of leaders and interpersonal communication networks in the Department of Education and Culture of West Kalimantan Province, the better the job satisfaction of the employees. Besides that, the amount of $\mathrm{R}=0.845$ which means that the magnitude of the influence of emotional intelligence and interpersonal communication variables together on job satisfaction is $84.5 \%$. Discussion

The results of the analysis that have been carried out and described earlier are answers to the formulation of the research problem. The main problem of this research has been answered, namely emotional intelligence and interpersonal communication have a significant and positive effect on employee job satisfaction. It is one of the considerations for the Office of Education and Culture of West Kalimantan Province regarding increasing employee job satisfaction.

The next discussion will examine the influence of each variable, namely the influence of emotional intelligence and interpersonal communication on job satisfaction of employees of the Department of Education and Culture of West Kalimantan Province.

1. The Effect of Emotional Intelligence on Job Satisfaction of Employees of the Department of Education and Culture of West Kalimantan Province

The results of the study indicate a positive and significant influence between the leadership emotional intelligence in the Department of Education and Culture of West Kalimantan Province on employee job satisfaction with a very strong correlation power $(r=0.848)$. It means that the better the emotional intelligence of the leaders, the higher the job satisfaction of the employees. The results of this study are in line with the research conducted by Meita Sondang Riski and Ausy Riana (2018) entitled The influence of work discipline, transformational leadership, and emotional intelligence on the satisfaction and performance of civil servants in the General Section and Protocol of the Regional Secretariat of East Kutai Regency which describes the influence of emotional intelligence with job satisfaction. Similarly, what was mentioned by Zaini Fadhli (2018) in his research entitled The influence of emotional intelligence on job satisfaction and organizational commitment as well as its impact on employee performance (case studies on the work unit of Aceh Jaya Regency) also stated that there was an influence between emotional intelligence on job satisfaction employee.

Emotional intelligence plays a role in shaping employee job satisfaction. As stated by Kreitner and Kinicki (2014: 142) which states that the ability to build a team, manage a team, collaborate and motivate a team towards a new direction is part of the implementation of the emotional intelligence of a leader. Leaders with good emotional intelligence will manage the team well too, motivating the team members to be creative and innovative towards new changes.

This emotional intelligence is reflected in the daily leadership. About how the leader recognizes his own emotions, manages his emotions, utilizes emotions for positive things, empathy, and fostering relationships. These daily activities will be seen and felt by the staff directly. There is an assessment of the leader's attitude in managing emotions intelligently so that whatever the conditions, employee job satisfaction can be 
maintained. Therefore, increasing the emotional intelligence of the leaders in the Department of Education and Culture of West Kalimantan Province must always be improved so that it can increase the job satisfaction of its employees as well.

2. Influence of Interpersonal Communication on Job Satisfaction of Employees of the Department of Education and Culture of West Kalimantan Province

The results of the study indicate that there is a positive and significant influence between interpersonal communication established in the Department of Education and Culture of West Kalimantan Province on employee job satisfaction with moderate correlation strength $(\mathrm{r}=0.451)$. It means that the better the interpersonal communication network, the higher the job satisfaction of the employee. The results of this study are in line with the research conducted by Banuara Nadeak (2018) in a study entitled Interpersonal Communication of Civil Servants in the Job Satisfaction of the Office of Education, Youth and Sports Kerawang Regency which states that there is an influence between interpersonal communication on employee job satisfaction.

Interpersonal communication is something that cannot be separated from social interaction. As mentioned by Robbin and Judge (2015: 51) which states that interaction with colleagues is closely related to employee job satisfaction. Quality interpersonal communication will provide comfort and tranquility in work so that employees feel happy with what is their current job.

The quality of interpersonal communication can be seen from various things. Among them are openness, sensitivity to others, confidence, delivery of support, as well as the ability to manage interactions and put themselves by the portions. The better and more intensive the interpersonal communication network of employees of the Office of Education and Culture of West Kalimantan Province will increase the job satisfaction of employees.

3. The Effect of Emotional Intelligence and Interpersonal Communication on Job Satisfaction of Employees of the Department of Education and Culture of West Kalimantan Province

The results of the study prove the existence of a positive and significant influence between emotional intelligence and interpersonal communication together on the job satisfaction of employees of the Department of Education and Culture of West Kalimantan Province. It means that the better the emotional intelligence of the leaders and the better interpersonal communication, the higher the job satisfaction of the employees.

As the opinion of Kreiner and Kinicki (2016: 143) which states that emotional intelligence is a person's ability to manage themselves and also in dealing with others. It means that someone with good emotional intelligence will have quality relationships with other people. It is also strengthened because emotional intelligence shapes not only one's competence but also social competence. Likewise, interpersonal communication, according to De Vito (2011: 32), has the main purpose of connecting with other people, as well as fostering and maintaining relationships with others.

Thus, it can be seen that between interpersonal communication and emotional intelligence are two things that support each other because both produce quality relationships with others. Likewise experienced by employees of the Department of Education and Culture of West Kalimantan Province. Based on the results of the research can be seen that most of the employees of the Department of Education and Culture of West Kalimantan Province, namely 21 people (70\%) felt that the emotional intelligence of their leaders was very good. It means that employees feel that their leaders have good emotional management for themselves and others and can empathize and establish quality relationships.

In addition, there are 21 people (70\%) employees of the Department of Education and Culture of West Kalimantan Province who feel that interpersonal communication is very good. It shows that communication between employees can provide comfort for other employees regarding awareness, management of interaction, immediacy, support, confidence, openness, flexibility, and oriented to others.

Because the two variables mentioned above are in a very good category, of course, it supports the high job satisfaction of employees. There are 21 employees $(70 \%)$ have very high job satisfaction. With this high job satisfaction, it will make employees display the best work as well. It is in line with what was stated by Robbin and Judge (2013: 119) which states that job satisfaction is a predictor of performance because job satisfaction has a moderate correlation with performance. Employees who have high job satisfaction will do their job obligations better.

This research also shows the value of $\mathrm{R}=0.845$ which means that the influence of emotional intelligence and interpersonal communication variables together on employee job satisfaction is $84.5 \%$. It implies that job satisfaction is also influenced by other factors.

As abstracted from the opinions of various experts (Kreitner and Kinicki, Newstorm, Robbins and Judge, and Sugiyono) that factors that influence employee job satisfaction are not only leadership emotional intelligence and interpersonal communication, but other factors influence it. These factors are (1) type of work, (2) welfare, (3) opportunities for advancement, (4) awards and penalties, (5) work environment, and (6) organizational conditions. Therefore, the Department of Education and Culture of West Kalimantan Province should try to increase employee job satisfaction through various other factors that influence it.

\section{CONCLUSIONS}

\section{A. Conclusions}

In general, it can be concluded that leadership emotional intelligence and interpersonal communication affect 
job satisfaction of employees of the Department of Education and Culture of West Kalimantan Province. The specific conclusions can be explained below:

1. Emotional intelligence leaders influence the job satisfaction of employees of the Department of Education and Culture of West Kalimantan Province significantly.

2. Interpersonal communication has a significant effect on the job satisfaction of employees of the Department of Education and Culture of West Kalimantan Province.

3. Leadership emotional intelligence and interpersonal communication together have a significant effect on job satisfaction of employees of the Department of Education and Culture of West Kalimantan Province.

\section{B. Suggestion}

Based on the results of research that has been done on employees of the Department of Education and Culture of West Kalimantan Province, it is recommended to:

1. The Office of Education and Culture of West Kalimantan Province must continue to maintain or even foster so that it can improve the emotional intelligence of leaders who have been felt very well by employees at this time.

2. The Department of Education and Culture of West Kalimantan Province must continue to maintain and intensify interpersonal communication of its employees even though currently employees have felt that interpersonal communication has been very good.

3. The Department of Education and Culture of West Kalimantan Province must maintain and even increase the job satisfaction of its employees, especially regarding some aspects which are considered to be still not optimal.

\section{REFERENCES}

Banuara Nadeak. 2018. Komunikasi Interpersonal Pegawai Negeri Sipil dalam Kepuasan Kerja. Jurnal Politicom Indonesiana Volume 3 Tahun 2018. (Online) diakses pada 14 Agustus 2018.

Devito Josep. 2016. Komunikasi Antar Manusia. Tangerang Selatan : Karisma Publishing Group.

Kreitner, Robert \& Kinicki Angelo. 2014. Perilaku Organisasi. Jakarta: Salemba Empat.

Meita Sondang Riski, Ausy Riana. 2018. Pengaruh Disiplin Kerja, Kepemimpinan Transformasional, dan Kecerdasan Emosional terhadap Kepuasan dan Kinerja PNS pada Bagian Umum dan Protokol Sekretariat Daerah Kabupaten Kutai Timur. Studi and Management Research Volume XV no. 1 Tahun 2018. (Online) diakses pada 14 Agustus 2018.

Robbins, Stephen P. \& Judge, Timothy A. 2013. Organizational Behavior. United States of America: Pearson.

Robbins, Stephen P. \& Judge, Timothy A. 2015. Perilaku Organisasi. Jakarta: Salemba Empat.

Sugiyono. 2015. Metode Penelitian dan Pengembangan; Research and Development. Bandung: Alfabeta.

Sutrisno, Edi. 2009. Manajemen Sumber Daya Manusia Edisi pertama. Jakarta: Kencana Prenada Media Group.

Undang-Undang RI No. 5 Tahun 2014 tentang Aparatur Sipil Negara.

Zaini Fadhli. 2018. Pengaruh Kecerdasan Emosional terhadap Kepuasan Kerja dan Komitmen Organisasi serta Dampaknya Terhadap Kinerja Pegawai (Studi Kasus pada Satuan Kerja Perangkat Kabupaten Aceh Jaya). Electronic Theses anda Disertation (ETD) 2018. (Online) diakses pada 14 Agustus 2018. 